\title{
Analyzing Spatial Distribution of Poverty Incidence in Northern Region of Peninsular Malaysia
}

\author{
Narimah Samat ${ }^{1}$, Siti Masayu Rosliah Abdul Rashid ${ }^{1} \&$ Yasin Abdalla Elhadary ${ }^{2}$ \\ ${ }^{1}$ Section of Geography, School of Humanities, Universiti Sains Malaysia, Penang Malaysia \\ ${ }^{2}$ Department of Geography and Environment, University of Khartoum, Sudan \\ Correspondence: Siti Masayu Rosliah Abdul Rashid. E-mail: masayurashid@usm.my
}

Received: October 9, 2018

doi:10.5539/ass.v14n12p86

\begin{abstract}
Poverty has been a major problem around the world for many years. Therefore eradicating poverty has become the first agenda in the United Nations Sustainable Development Goals (SDGs) as its achievable target. In Malaysia, poverty rate is relatively low, decreasing from $49.3 \%$ in 1970 to $15 \%$ in 1990 , then, to merely $0.6 \%$ in 2014. Although poverty rate is very small, it is reported at a state level which is to general to visualize its actual distribution. Furthermore, it fails to capture geographic variation within the state. This study aimed to analyze the spatial distribution of poverty incidence in the northern region of Peninsular Malaysia at a sub-district level using Geographic Information System (GIS). GIS was used to map poverty rate, demographic burden and poverty hotspot in the study areas. The poverty data were obtained from $e$-Kasih database. Furthermore, the accessibility of each sub-district to major urban centers, higher education institutions, and health facilities were also measured. Results indicated that poverty rate was highly correlated with regional differentiation, where location played a significant role in identifying areas with a high number of poor populations. Sub-districts with high poverty rate were less accessible to major urban centers, higher education institutions and health facilities. The findings also indicated that access to opportunities and facilities remained the major concerns in solving the poverty issues in Malaysia. It is timely, therefore, a spatial dimensional approach used to complement the existing poverty eradication strategies.
\end{abstract}

Keywords: poverty, Malaysia, spatial distribution, Geographic Information Systems (GIS), poverty rate, poverty eradication

\section{Introduction}

Poverty alleviation has been a major attention by planners and decision-makers not only in developing countries but in developed nations. Various strategies and agendas such as providing a continuous education, improving a living standard of rural society, improving the agricultural sector, and introducing ICT to promote economic opportunities. These strategies and agendas do not completely eradicate poverty, they have, however, successfully reduced the incidence of poverty at certain levels. Poverty has been viewed from various dimensions in order to better tackle this issue. The World Bank (2016), for example, viewed income poverty, education and health poverty, tenure insecurity, personal insecurity, income insecurity, and social and political exclusion/disempowerment as six dimensions of poverty. In addition, poverty can also be seen from the geographical perspective where space or location has become one of the poverty determinants (Vista \& Murayama, 2011; Samat et al., 2016). This approach has started to gain its important in describing the conditions, visualizing the location of the poor and identifying the relationship between the location of the poor with the surrounding environment or infrastructures (Moral, 2010; Muhamed \& Haron 2011; Samat et al., 2016).

Various studies have shown that geographical or spatial dimensions are among important determinants in identifying the distribution of poverty incident. According to Samo (2016), geographic dimensions through Geographic Information Systems (GIS) can help to identify spatial distribution of poverty. This information can assist in tackling poverty issues by reducing the impact of natural disasters, planning for the distribution of relief operations, understanding social issues, sourcing the distribution information, and managing for maximizing the agricultural produce. GIS allows us to visualize, question, analyze, and interpret the data to better understand the relationships, patterns, and trends (ESRI, 2016). A study by Amarasinghe et al. (2005) in Sri Lanka using GIS and spatial analysis revealed two clusters based on nutrition-based poverty line. The first cluster indicated low 
poverty rural areas, where populations in those areas had low agricultural employment and better access to roads. The second cluster indicated high poverty rural areas, where agriculture was the dominant economic activity. Thus, among main factors for the poverty incidence in rural areas were water availability and poor access to irrigation. Similarly the study by Michalek (2004), in Slovakia used spatial differences to identify poverty centers. The poor among rural communities were involved children. Moreover high level of poverty was influenced by factors such as nature, politics, economy and social (Michalek, 2004). Another study conducted by Vista and Murayama (2011) in Albay and Camarines Sur Provinces in Bicol Region, Philippine found that access to road infrastructure, nearness to main markets, rate of land distribution, bias in fiscal decentralization policy, and aspects of agro-climatic condition such as elevation, slope, and rainfall had significant effects on poverty incidence. Most of the studies concluded that geography and facets of public policy had a strong impact on the state of poverty (Michalek, 2004; Amarasinghe et al., 2005). Similarly, the study by Kneebone (2014) in the United States indicated the poor concentrated in highly disadvantaged neighborhoods. People living within those areas faced various issues such as worse health outcome, high crime rate, high school dropout, and few job opportunities. In Malaysia, Samat et al. (2012) and Samat and Shattar (2014) used a spatial dimensional approach to visualize poverty and access to services. This study indicated rural communities had limited access to infrastructure and facilities. Similarly, Samat (2013) used GIS to map the poverty rate in Malaysia, allowing spatial differentiation among states to be visualized. Those studies indicated location as one of the important determinants of poverty.

\subsection{The Monetary Approach}

The monetary approach was pioneered by Booth and Rowntree (as cited from Laderchi et al., 2003), who studied poverty incidence in London and New York in the late 18th and early 19th centuries, respectively. Rowntree (1902) stated that poverty line could be estimated as monetary requirements for a nutritionally adequate diet together with estimated needs for clothing and rent. Those below this line were defined as in primary poverty and those who were seen in "obvious want and squalor" despite being above the defined poverty line were classified as being in secondary poverty (Laderchi, 2003). The monetary approach uses income/expenditure technique to identify the poor (Mitlin, 2004) through the absolute poverty concept. Under this approach, poverty may either be defined in terms of international monetary line approach or national poverty line approach (PLI). PLI aims to measure the minimum requirement of basic needs (food and none-food) consumed by a household. This approach enlists access to shelter sanitation, clean water and health facilities as none-food basic needs. Hence, households fall below the PLI are considered poor and vice versa.

The PLI indicators used in monetary approach are rather similar to Had al kifayah; the method adopted in Islamic beliefs to determine the poor (Abdul Rasool et al., 2011). According to Islamic principle, people who fall below the Had al kifayah are in need to be supported with Zakat, an Islamic form of congregational funding. The current empirical evidence has shown that monetary approach is widely used in most of the Asian Pacific countries including Malaysia. In its 9th Malaysia's Plan (EPU, 2006), poverty line indicated the lack of monetary ability to procure basic needs, measured by non-food and food needs. The monetary approach is widely used since it is easy to compute as it is based on monetary calculation. However, this approach often neglects the qualitative aspects of being poor such as the lack of comfort, health, personal safety, and social inclusion. The approach also fails to capture the effective achievements in terms of human lives (Laderchi, 2003).

\subsection{The Capability Approach}

The capability approach was originally developed by Sen (1977) and Sen (1992) who defined poverty as the deprivation of basic capabilities that provide a person with the freedom to choose the life he/she has reason to value or failure to achieve certain minimal or basic capabilities. This approach is implicitly rejected income as a measure of well-being. The approach conveyed an ethical critic of mainstream development by rejecting the dominant belief that income is an adequate measurement of human's well-being (Sen, 1992). Translating the capability approach into an operational framework for poverty evaluation requires one to list the basic capabilities. Although total indicators of basic capabilities were not provided, Sen (1987) suggested that life expectancy, literacy and infant mortality are the main approaches to measure poverty. He concentrated on the quality of life and emphasized on removing the obstacles in order for people to gain more freedom to function. Elhadary and Samat (2012) added good health, education, social networks and command over economic resources. While Alkire (2002) argued that the lack of specification was deliberate in order to allow room for choice across societies and ensure the relevance of the approach to different persons and cultures. Similarly, Nussbaum (2003) argued that there is an overlapping consensus between different societies on the conception of a human being and what is needed to be fully human. 
The strength of capabilities approach lies in its multidisciplinary characters where it focused on the plural or multidimensional aspects of well-being (Robeyns, 2005). Therefore, it has been used in the Human Poverty Index (HPI), which is a composite index of multiple dimensions of poverty and well-being (UNDP, 2007). HPI used the three deprivation elements: longevity, knowledge and a decent standard of living. Indicators for these three elements include having less than 40 years life expectancy at birth, adult illiteracy, and an average of not using improved water sources and under-five mortality. The approach effectively uncovers the causes that affect poverty. Therefore, poverty should be addressed not only through incomes support, but also other dimensions such as education and healthcare. The development should be seen as the expansion of human capabilities, not the maximization of utility, or its proxy i.e. money (Sen, 1992).

Unlike monetary, the capability approach provides a coherent framework to define poverty in the context of the lives people live and the freedom they enjoy. This approach is useful for policy formulation as it highlights the causes of being poor. Yet, like the monetary approach, implementing capability approach at operational measures poses a number of challenges. For instance, there is no definitive list of relevant capabilities (Nussbaum, 2003), and it is difficult to clearly delineate the line between the poor and non-poor. The approach has been called too individualistic (Deneulin \& Stewart, 2002), non-operational and unpractical (Sugden, 1993). Sugden (1993) found that the Human Development Index (HDI), to be empirically weak with serious problems of non-comparability over time and space. This limits their usefulness for short-term and medium-term poverty monitoring (Lok-Dessallien, 1998). The capability approach suggests poverty reduction policy on investments in extending and exercising basic capabilities through the provision of monetary income and improved allocation of social goods to achieve education, health and other goals. One important policy assumption for both approaches (the monetary approach and the capability approach) is that growth is good for the poor. Both approaches largely fail to directly capture the fundamental causes and dynamics of poverty. The solutions they propose to poverty may, therefore, be misleading.

\section{Background of Study}

Based on its various definition, poverty can be classified into three groups; (1) absolute poverty, based on the concept of minimum food and non-food concepts for households, (2) relative poverty, which illustrates the disproportionate living conditions among the whole household based on income groups, strata and so on; and (3) subjective poverty which is the nature of something that cannot be achieved (Henry \& Amir, 2011; Muhammad bin Idris, 2016). The classification is mainly based on PLI and is used for strategic policy intervention.

Several international policies have been adopted to eradicate poverty. Among these was the Millennium Development Goals (MDG) which ended in 2015. The MDG report 2015 indicated that the 15 -year effort to achieve the eight goals set out in the Millennium Declaration in 2000 was largely successful across the globe while acknowledging few shortfalls that remain. For example, the number of people living in extreme poverty has tremendously declined by more than half, falling from 1.9 billion in 1990 to 836 million in 2015 (UNDP, 2016). The data presented indicated that global effort with targeted interventions, sound strategies, and adequate resources managed to successfully reduce the number of people with extreme poverty. However, the number of poor remains high within certain areas and regions. Thus, concerted effort to eradicate poverty continues where it becomes the first agenda within Sustainable Development Goals (SDGs), subsequent global effort towards sustainable development after MDG. In addition, intention of SDG with no one is left behind is to ensure that these commitments are translated into effective action requires a precise understanding of target populations (The Sustainable Development Goals Report, 2016). According to this intention, it will potentially lead to the success of the 2030 Agenda for Sustainable Development in addressing the issue of the spatial distribution of poverty incidence. This agenda gains a global support, reaching an agreement to end poverty and hunger in all their forms and dimensions, and ensuring all human beings can fulfill their potential in dignity and equality and in a healthy environment between now and 2030 (United Nations, 2015).

Various studies have shown that poverty rate was high among countries that predominantly depended on agriculture sector as the main economic activity (Moral, 2010; Mwabu \& Thorbecke, 2016). Thus, increasing agriculture productivity is seen as one of the main actions to eradicate poverty (Gollin, 2015). There are six factors that could improve agriculture productivity, hence, eradicate poverty (Jones, 2015; Mwabu \& Thorbecke, 2016). These factors are (1) increase research studies on plant breeding by focusing on the type of soil, (2) improve irrigation and drainage systems, (3) increase the use of fertilizers, (4) improve market access and rural infrastructure, (5) use a better information technology; and (6) improve land ownership system. The increase in agriculture productivity would have resulted in the reduction of the poverty rate, mainly due to the increase of income level among farmers, improve health and nutrition, lower food prices, and create more opportunities to the communities (Schneider \& Gugerty 2011; Mwabu \& Thorbecke, 2016). Therefore, poverty eradication 
strategy in areas that are highly depended on agriculture activities should focus on transforming the agriculture sector by increasing the farm productivities and by marketing the agriculture products to national and international markets (Jones, 2015).

In Malaysia, for example, agriculture sector was once the largest contributor of its Gross Domestic Product (GDP). However, in the 1970s the government embarked on industrialization policy which successfully transformed the economy from agriculture- based to industrialization-based policy. It is worth noting that the poverty rate in Malaysia has been well-alleviated at a national level where the poverty rate reduced from $49.3 \%$ in 1970 to $15 \%$ in 1990 , then, to $0.6 \%$ in 2014 (EPU, 2015). This success was due to the rational policy adopted by the Malaysian government to eradicate poverty and ensure equity among all its inhabitants (Elhadary \& Samat 2012). Numerous policies were introduced and implemented including Pre-New Economic policy (PNEP) 1960-1970, New Economic Policy (NEP) 1971-1990, National Development Policy (NDP) 1991-2000, National Vision Policy (NVP) 2001-2010 and Government Transformation Plan (NTP) 2011-2020, aiming to nurture economic growth and eliminate overall poverty in the country (EPU, 2015).

Studies have shown that implemented policies and its related agendas have succeeded in promoting the economic growth, thus, reducing the incidence of poverty in Malaysia (Elhadary \& Samat, 2012; Abdul Manaf \& Ibrahim, 2017). Political stability, good governance, racial integrity and ethnic harmony, as well as a close national unity are among contributing factors in the poverty eradication agendas. Several other initiatives such as the establishment of Federal Land Development Authority (FELDA) focusing on oil palm and rubber plantations in the 1970s and various rural development strategies were continuously implemented to promote socio-economic progress among Malaysians. Recently, the government initiated a proper documentation by developing a centralized database known as e-Kasih used to measure poverty level in the state in its poverty eradication programs. Programs such as 1AZAM and 1Malaysia were also introduced by the government for poor families (Abdul Manaf \& Ibrahim, 2017; Abdul Razid, 2013; Shamsulbahriah \& Norma, 2013). 1AZAM program, for example, intended to assist the poor to start their own business or project to improve socio-economic status. While, 1Malaysia program which included the opening of the 1Malaysia Shop grocery store (Kedai Rakyat 1Malaysia-KR1M), 1Malaysia clinics (K1M), Rural Transformation Centers (RTC) and Urban Transformation Centers (UTC) are among initiatives to reduce the burden of high cost of living faced by the people (Samat et al., 2016). As a record, 1Malaysia Shop was established in 2011 using the concept of mini market which sells various basic needs at low prices. The 1Malaysia Shop initiative is aimed at alleviating the burden of low income people living in urban areas.

Although the policies and agendas implemented managed to reduce the poverty rate, the incidence of poverty is slightly higher in some geographical areas (Table 1) (EPU, 2013; Abdul Khalid, 2014). As tabulated below, the poverty rate in Malaysia in the year 2012 was 1.7 percent although few states such as Sabah (7.8 percent), Kelantan (2.7 percent), and Sarawak (2.4 percent) noted a higher poverty rate than the national rate (EPU, 2015). Bumiputera (Malays) indicated the highest poverty rate ( 2.2 percent) among major ethnic groups in Malaysia, followed by Indian as the second highest (1.8 percent). Chinese, on the other hand, had the lowest poverty rate which was 0.3 percent. Regional differentiation also can be visualized between urban and rural areas, where the rate was 1.0 percent and 3.4 percent, respectively. In 2014, the rate has declined to 0.6 percent (EPU, 2015) despite higher poverty rate was noted by few states such as Sabah (3.9 percent), Sarawak ( 0.9 percent), Kelantan ( 0.9 percent), Pahang ( 0.7 percent) and Perak ( 0.7 percent). The status of Bumiputera (Malays) as the poorest among ethnic groups remained unchanged although the poverty rate of this group managed to be reduced from 2.2 percent to 0.8 percent. Meanwhile, Indian and Chinese also experienced a similar situation, of which the poverty rates reduced to 0.6 percent and 0.1 percent, respectively. In terms of strata, rural areas recorded 1.6 percent poverty rates, while 0.3 percent for urban areas.

While the incidence of poverty was significantly alleviated in Malaysia, pockets of poverty exist with high incidence among specific ethnic groups and localities (Mohamed \& Xavier, 2015). In the same line, Nair (2010) indicated that rural, urban and absolute poverty remain critical problems need to be resolved. Thus, targeted intervention strategies are required to spatially address poverty incidence in Malaysia. This approach is significant as Malaysia is moving towards a high-income nation by 2020. Furthermore, the strategy should be focused on addressing the absolute poverty to relative poverty (Elhadary \& Samat, 2015). Referring to Table 1, although poverty is not entirely eradicated in Malaysia, a tremendous decline in poverty incidence can be observed in this country (Nair, 2010; EPU, 2015). At present, the strategy is focusing more on improving the socio-economic condition by moving low-income earners towards high-income populations (EPU, 2015). (Refer Table 1).

Although the poverty rate in Malaysia is relatively low, regional differences can still be seen where few states 
have the poverty rate higher than the national poverty. Thus, in order to clearly visualize areas affected by poverty, a spatial dimension approach may be used. The spatial dimensional approach uses GIS analytical capabilities to visualize and establish spatial relationship between poverty and other geographical factors (Moral, 2010; Kneebone, 2014). GIS provides a platform for analyzing spatial and non-spatial data and for testing possible policy scenarios prior to its implementation.

Table 1. Incidence of Poverty by Ethnicity, Strata and State, Malaysia, 1970-2014

\begin{tabular}{|c|c|c|c|c|c|c|c|c|}
\hline Year & 1970 & 1984 & 1992 & 1997 & 2002 & 2009 & 2012 & 2014 \\
\hline Malaysia & 49.3 & 20.7 & 12.4 & 6.1 & 6.0 & 3.8 & 1.7 & 0.6 \\
\hline \multicolumn{9}{|l|}{ Ethnic } \\
\hline Bumiputera & 64.8 & 28.7 & 17.5 & 9.0 & 9.0 & 5.3 & 2.2 & 0.8 \\
\hline Chinese & 26.0 & 7.8 & 3.2 & 1.1 & 1.0 & 0.6 & 0.3 & 0.1 \\
\hline Indian & 39.2 & 10.1 & 4.5 & 1.3 & 2.7 & 2.5 & 1.8 & 0.6 \\
\hline Others & 44.8 & 18.8 & 21.7 & 13.0 & 8.5 & 6.7 & 1.5 & 0.9 \\
\hline \multicolumn{9}{|l|}{ Strata } \\
\hline Urban & 21.3 & 8.5 & 4.7 & 2.1 & 2.3 & 1.7 & 1.0 & 0.3 \\
\hline Rural & 58.7 & 27.3 & 21.2 & 10.9 & 13.5 & 8.4 & 3.4 & 1.6 \\
\hline \multicolumn{9}{|l|}{ State } \\
\hline Johor & 45.7 & 12.2 & 5.6 & 1.6 & 2.5 & 1.3 & 0.9 & 0.0 \\
\hline Kedah & 63.2 & 36.6 & 21.2 & 11.5 & 9.7 & 5.3 & 1.7 & 0.3 \\
\hline Kelantan & 76.1 & 39.2 & 29.5 & 19.2 & 17.8 & 4.8 & 2.7 & 0.9 \\
\hline Melaka & 44.9 & 15.8 & 8.5 & 3.5 & 1.8 & 0.5 & 0.1 & 0.1 \\
\hline Negeri Sembilan & 44.8 & 13.0 & 8.1 & 4.7 & 2.6 & 0.7 & 0.5 & 0.4 \\
\hline Pahang & 43.2 & 15.7 & 6.9 & 4.4 & 9.4 & 2.1 & 1.3 & 0.7 \\
\hline Pulau Pinang & 43.7 & 13.4 & 4.0 & 1.7 & 1.2 & 1.2 & 0.6 & 0.3 \\
\hline Perak & 48.6 & 20.3 & 10.2 & 4.5 & 6.2 & 3.5 & 1.5 & 0.7 \\
\hline Perlis & 73.9 & 33.7 & 19.8 & 10.7 & 8.9 & 6.0 & 1.9 & 0.2 \\
\hline Selangor & 29.2 & 8.6 & 4.3 & 1.3 & 1.1 & 0.7 & 0.4 & 0.2 \\
\hline Terengganu & 68.9 & 28.9 & 25.6 & 17.3 & 14.9 & 4.0 & 1.7 & 0.6 \\
\hline Sabah/F.T. Labuan & & 33.1 & 27.8 & 16.5 & 16.0 & 19.2 & 7.8 & 3.9 \\
\hline Sarawak & & 31.9 & 19.2 & 7.3 & 11.3 & 5.3 & 2.4 & 0.9 \\
\hline F.T.Kuala Lumpur & & 4.9 & 1.7 & 0.1 & 0.5 & 0.7 & 0.8 & 0.1 \\
\hline F.T Putrajaya & - & - & - & - & - & - & - & - \\
\hline
\end{tabular}

Source: Economic Planning Unit (EPU)

\section{Materials and Methods}

This paper aimed to map the poverty rate and analyzed the spatial distribution at a local level. This study was undertaken in the northern regions of Peninsular Malaysia comprising of four states namely Perlis, Kedah, Penang and North Perak (Figure 1). This area was chosen as study area since these states are under Northern Corridor Economic Region, a regional development strategy intended to focus and aim to function as function as Malaysia's modern agriculture zone, attraction for tourists' destinations, and regional leader in the electronics and electrical sectors. Furthermore, these states are designed to become a world-class economic region by 2025 for people to invest, live and bring up families in a safe, clean and sustainable environment (Sime Darby Berhad, 2007). With the exception that had poverty rate of 0.7 in Perak, other states indicated the poverty rate of lower than national poverty rate (EPU, 2015). However, the value might be different at a local level or if poverty is reported on a bigger scale such as district or sub-district level.

Data used in this study were obtained from poverty database called $e$-Kasih maintained by the Implementation Coordination Unit (ICU), Prime Minister Department, Malaysia. e-Kasih system is a database system for poor families that's created at the national level to help design, implement and monitor poverty program. e-Kasih system was established following the decision of the Malaysia Government Cabinet on 2007. Data and information included in $e$-Kasih is based on the Census of Poor Households which is a program of the census of households and non-individuals. It is run by the Department of Statistics Malaysia Official with census results submitted to the ICU Prime Minister Department as a key input to e-Kasih (The Department of Statistic Malaysia, 2015). 


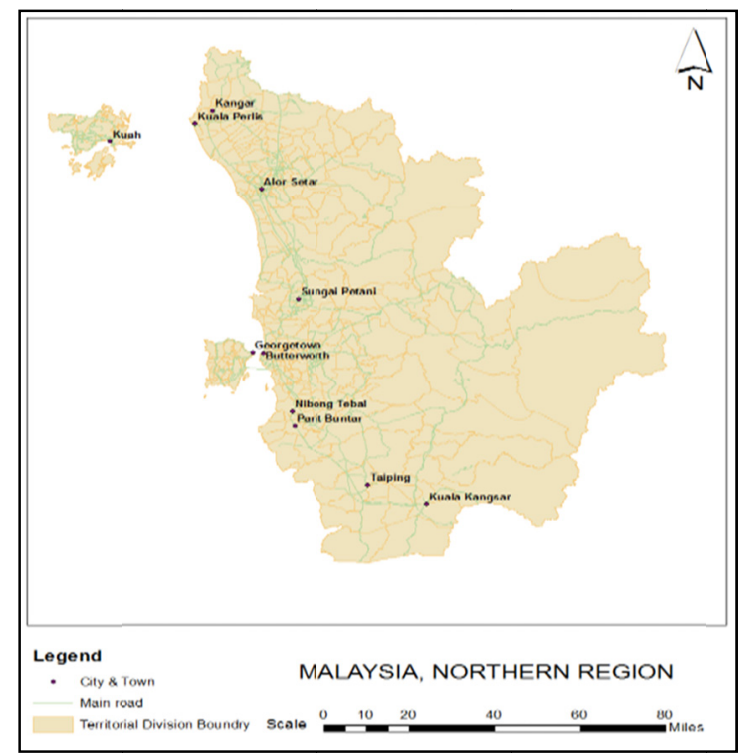

Figure 1. The study area - Northern Region of Peninsular Malaysia

In addition, the mechanism of open enrolment in e-Kasih is also the source of data and information contained in $e$-Kasih database system. Households verified in the field and meet the eligibility criteria of $e$-Kasih are eligible for inclusion into e-Kasih 2010. In addition to those who meet the eligibility criteria of poverty status based on per capita household Poverty Line Income 2007, eligibility for registration and included in the e-Kasih are households with an income of less than RM 1000 per month for the rural population and RM 1500 a month for residents in the city. Detailed registration will be done by the enumerator for the purpose of verification and then to be registered in the e-Kasih database system confirmed by the focus group, comprising the District Office and the ICU at the state level (Nor \& Azhar, 2016).

The unit of analysis given was an individual record, but for mapping purposes, a sub-district record (mukim) was used. The poverty rate was mapped, where the proximity of each sub-district to hospitals and urban centres was calculated. Then, the hot and cold spots of the poverty rate were investigated.

Referring to Roser and Ortiz-Ospina (2018), poverty rate was calculated by Equation (1) below;

$$
\begin{gathered}
\text { Pov_rate }=(\text { No_Poor } / \text { POP 2010 }) * 100 \\
\text { Where, } \\
\text { Pov_rate }=\text { Poverty Rate } \\
\text { No_Poor }=\text { Number of Poor population, } \\
\text { POP2010 }=\text { Total Population of years } 2010
\end{gathered}
$$

The spatial proximity of each sub-district to existing infrastructures was also measured. This was undertaken by using NEAR function which measured the proximity of each sub-district to hospitals and the proximity of each sub-district to urban centers. Finally, the study mapped the cold and hot spot for poverty in each study area. ArcGIS 10.1 software was used to manage the database, perform the analysis and display the map (ESRI 2016). The hotspots of the poverty incidence was measured using Getis-Ord Gi* function to identify the hot and cold spots of poverty. The resultant $Z$ score indicated the values (high or low) of poverty rate spatially (ESRI 2016). Hot and cold spots indicated sub-districts with high and low poverty rates within the study areas, respectively. The map provided an indication for planners and policy makers on targeted areas for intervention strategy.

\section{Results and Discussions}

Based on GIS analysis, the map showed that the poverty rate in the study area ranged from $0-2.55$ (Figure 2). An approximate 63 sub-districts had the poverty rate of more than 0.6 and 30 sub-districts had the poverty rate of 1.0 and above. These sub-districts exceeded the national poverty rate (EPU 2015). Most of these sub-districts were located in Kedah and Perlis (Figure 2 and Table 2). Table 2 indicated poverty rate calculated using Equation 1 where Sok district in Kedah showed the highest poverty rate (2.55), followed by two districts in Perlis i.e. Chuping (2.18) and Abi (1.87). Thus, the strategy to eradicate the poverty should be focused and targeted to these three districts. (Refer Figure 2 and Table 2). 


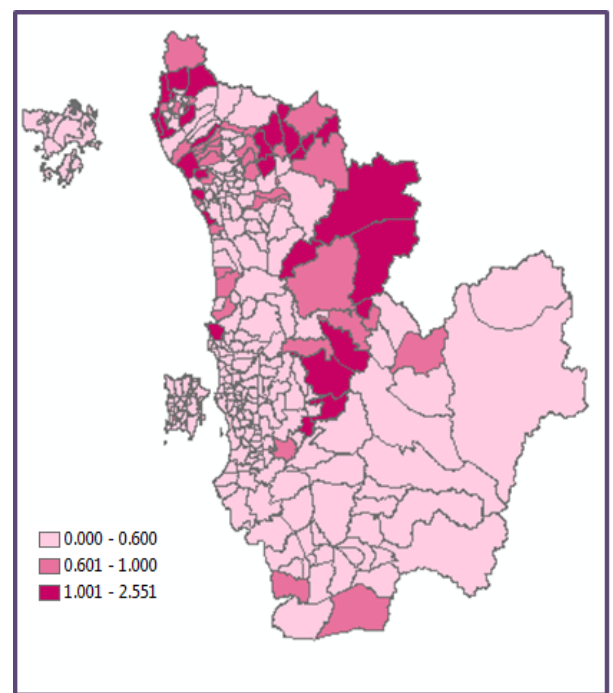

Figure 2. Poverty rate by sub-districts in Northern Region of Peninsular Malaysia, 2010

Table 2. Sub-districts with the highest poverty rate in the Northern Region, 2010

\begin{tabular}{cccc}
\hline No. & Sub-district & State & Poverty Rate \\
\hline 1 & Sok & Kedah & 2.55 \\
2 & Chuping & Perlis & 2.18 \\
3 & Abi & Perlis & 1.87 \\
4 & Batang Tunggang Kanan & Kedah & 1.84 \\
5 & Ah & Kedah & 1.79 \\
6 & Arau & Perlis & 1.77 \\
7 & Jeneri & Kedah & 1.70 \\
8 & Siong & Kedah & 1.67 \\
\hline
\end{tabular}

Figure 3 shows the map of 30 sub-districts with the poverty rate of more than 1.0 for 2010 data and where 1Malaysia Shop situated. As mention in earlier discussion, 1Malaysia Shop was established in 2011 with the aimed of easing the burden of the lower income group living in urban areas. However, as clearly shown on the map, most of 1Malaysia Shop was not located on sub-districts with high poverty rate. This shop should be located to the nearest targeted population since the purpose of 1Malaysia Shop was to ease the burden among the poor and low-income populations due to high living cost.

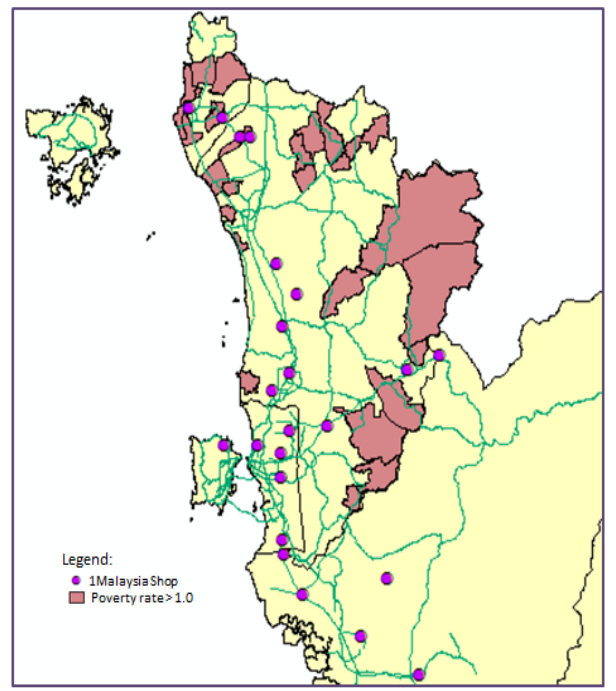

Figure 3. Sub-districts with poverty rate above 1.0 for year 2010 and location of 1Malaysia Shop

All sub-districts in Penang and Northern Perak had the poverty rate of less than 0.6 (Figure 2). This study, then calculated accessibility of each sub-districts to nearest major urban areas and health facilities, since accessibility 
to opportunities has a significant influence on poverty (Vista \& Murayama, 2011).

Several sub-districts such as Sik and Hulu Perak were fairly distant from existing higher education institutions with the farthest away were more than $50 \mathrm{~km}$. Both areas were also far from existing health centres, approximately $56 \mathrm{~km}$ away centres. This was probably due to the topographical factor and low population density within these areas, thus, no facility was located there.

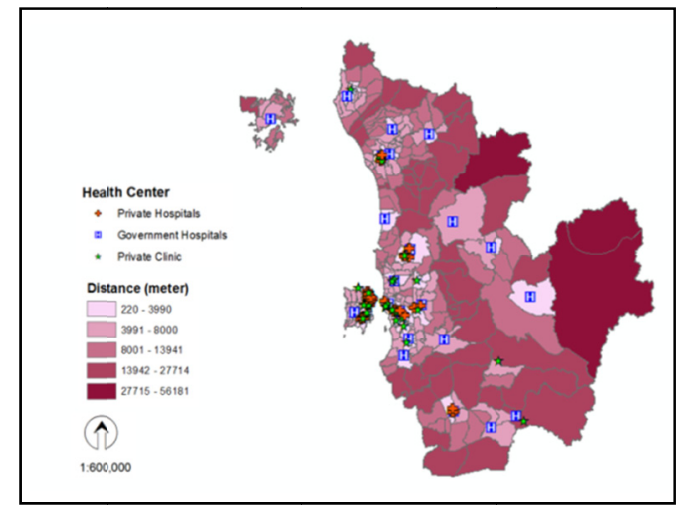

a. Proximity of sub-districts to nearest hospitals

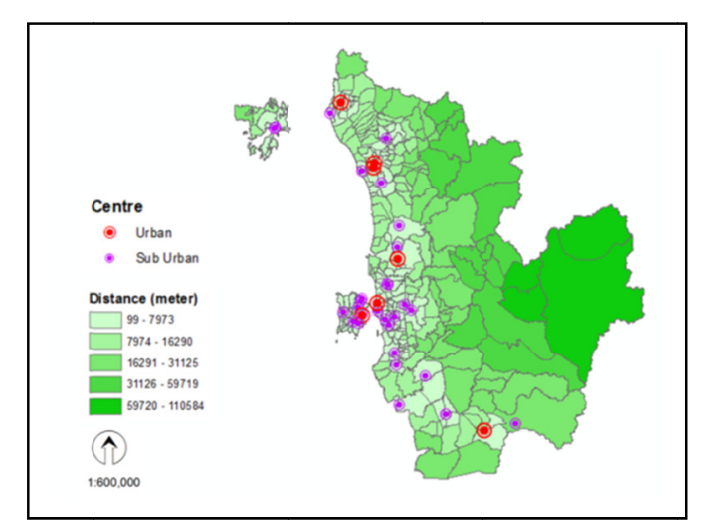

b. Proximity of sub-districts to nearest urban centers

Figure 4. Accessibility of sub-districts to (a) health facilities and (b) urban centres in 2010

Figure 4a indicates the location of health facilities in the sub-districts of all states. The public hospital was located in each district contrasted to private hospitals and clinics, which were mainly located in the major urban centres. From the map, sub-districts (represented by the darkest colour) with the farthest location from hospitals were approximately $56 \mathrm{~km}$ away. A similar pattern can be seen in urban and sub-urban centres which mainly concentrated along major roads of which some sub-districts were located more than $50 \mathrm{~km}$ from major urban centres. From the maps, few sub-districts were considered as far $(>50 \mathrm{~km})$ from major urban areas. Limited access to major urban areas might be one of the contributing factors of poverty in these sub-districts since the urban areas potentially provided a greater employment opportunity and better services to the populations.

Figure 5 indicates the hot and cold spots of poverty incidence in the sub-districts studied. Most districts in Kedah and all districts in Perlis were identified as hotspot areas or having high poverty rate. On the other hand, Penang and northern Perak were identified as cold spot areas or having low poverty rate. These patterns can be associated with economic activities of these states. Areas with agriculture-based activities are likely to have high poverty rate (Mwabu \& Thorbecke, 2016; Gollin, 2015) compared to areas concentrating on industrialization and tourism activities (Elhadary et al., 2013). Thus, increasing the agriculture productivity is one of the possible approaches to eradicate poverty in these study areas. Moreover, involvement in agro-based activities would assist the farmers to earn a higher and better household income (Elhadary et al., 2013). (Refer Figure 5).

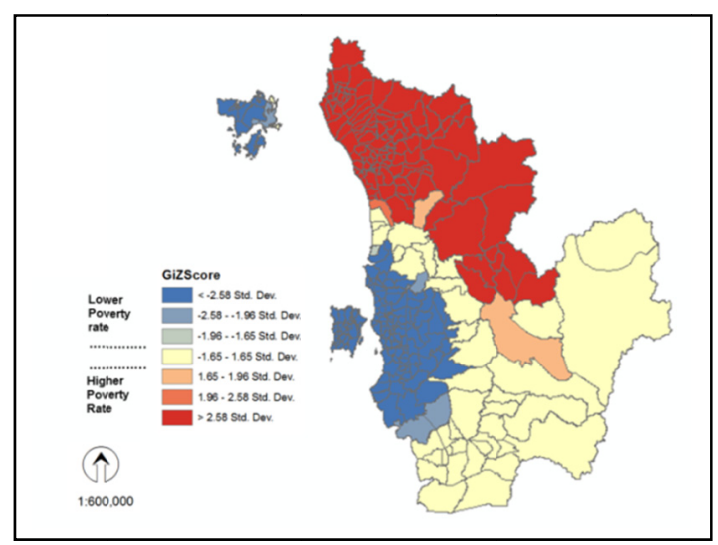

a. Hotspot of poverty rate in 2010

Figure 5. Statistically significant hot spot calculated using Getis-Ord i* using ArcGIS 10.1 software.

Based on the previous studies, poverty rate reported at a state level failed to capture local differences among sub-districts. Thus, intervention strategy used to eradicate poverty unable to cater for pocket of poverty. General statistics showing poverty rate at national or state level might not be able to portray the exact location that needs 
interventions. GIS analysis used in this study could be used to generate maps of high and low concentrations of poverty, providing useful information for planners to identify the appropriate location for intervention strategies and resource allocations.

\section{Conclusion}

As a long-standing issue for many countries, poverty needs to be viewed from various perspectives. Apart from six dimensions of poverty, a spatial dimensional approach is also relevant in investigating the poverty rate at any targeted area. This study explored the application of GIS in mapping the poverty rate by investigating the spatial accessibility of sub-district populations to health facilities and major urban centers in the northern region of Peninsular Malaysia, simultaneously mapping the hot and cold spots of poverty. With its analytical capability of combining data from various sources and scales, GIS provides a useful way in analyzing the poverty data. This approach could be used to complement the existing methods to formulate appropriate intervention strategies and resource allocation to sustainably eradicate poverty. Further analysis, however, is needed to establish a spatial correlation between the incidence of poverty and geographical factors identified in this study.

\section{Acknowledgement}

The authors would like to thank Universiti Sains Malaysia for funding this project through Research University Team Grant (1001/PHUMANITI/856002) and funded Siti Masayu Rosliah Abdul Rashid under USM-postdoctoral program, Mr Azmeer Abu Bakar and Mr Amirul Najmi for helping to gather spatial data and compile poverty data used in this study.

\section{References}

Abdul Khalid, M. (2014). The Color of Inequality. Kuala Lumpur: MPH Publishing Group.

Abdul Manaf, N., \& Ibrahim, K. (2017). Poverty Reduction for Sustainable Development: Malaysia's Evidence-Based Solutions. Global Journal of Social Sciences Studies, 3(1), 29-42. https://doi.org/10.20448/807.3.1.29.42

Abdul Razip, M. A. (2013). Kejayaan Malaysia dalam Program Basmi Kemiskinan. Jabatan Penerangan Malaysia, Putrajaya: Malaysia.

Abdul Rasool, M. S., \& Salleh, A. M. (2014). Non-Monetary Poverty Measurement in Malaysia: A Maqasid Al-Shariah Approach. Islamic Economics Studies, 22(2), 33-46. https://doi.org/10.12816/0008094

Alkire, S. (2002). Valuing Freedoms. Sen's Capability Approach and Poverty Reduction. Oxford University Press. https://doi.org/10.1093/0199245797.001.0001

Amarasinghe, U., Samad, M., \& Anputhas, M. (2005). Spatial Clustering of Rural Poverty and food insecurity in Sri Lanka. Food Policy, (30), 493-509. https://doi.org/10.1016/j.foodpol.2005.09.006

Berhad, S. D. (2007). Northern Corridor Economic Region Socioeconomic Blueprint 2007-2025. A Report Submitted to Government of Malaysia, 30th July.

Deneulin, S., \& Stewart, F. (2002). Amartya Sen's contribution to development thinking. Studies in Comparative International Development, 37(2), 61-70. https://doi.org/10.1007/BF02686262

EPU - Economic Planning Unit. (2006). Key Economic Indicators 2002-2006, Department of Statistics, Bank Negara Malaysia and the Bursa Malaysia

EPU - Economic Planning Unit. (2015). Report on Basic Household Income and Amenities Survey 2014, Department of Statistics, Malaysia.

Elhadary, Y., \& Samat, N. (2012). Political economy and urban poverty in the developing countries: lessons learned from Sudan and Malaysia. Journal of Geography and Geology, 4(1), 212-223. https://doi.org/10.5539/jgg.v4n1p212

Elhadary, Y., Samat, N., \& Obeng-Odoom, F. (2013). Development at the Peri-Urban Areas and Its Impact on Agriculture Activities: An Example from Seberang Perai Region, Penang State, Malaysia. Agroecology and Sustainable Food Systems, 37, 834-856. https://doi.org/10.1080/21683565.2013.797950

Elhadary, Y., \& Samat, N. (2015). Malaysia Towards Zero Poverty by 2020 in Proceedings of International Conference on Development and Socio Spatial Inequalities: Bridging Socio-Spatial Inequalities through Inclusive Development, Bayview Beach Resort, Penang, Malaysia, 19-20 August 2016. pp.1-8.

ESRI. (2016). Hot Spot Analysis (Getis-Ord Gi*). Retrieved from http://desktop.arcgis.com/en/arcmap/10.3/tools/spatial-statistics-toolbox/hot-spot-analysis.htm 
Gollin. D. (2015). Agriculture as an Engine of Growth and Poverty Reduction: Lessons for Africa. Chapter 4 in Economic Growth and Poverty Reduction in Sub-Saharan Africa: Current and Emerging Issue, ed. Andrew McKay and Erik Thorbecke (Oxford: Oxford University Press).

Henry, N. C. T., \& Amir, H. B. (2011). Poverty reduction: A continuous social responsibility in Malaysia. International Journal of Rural Studies (IJRS), 18(2), 1-4. Retrieved from http://www.vri-online.org.uk/ijrs/Oct2011/Poverty\%20Reduction\%20in\%20Malaysia.pdf

Kneebone, E. (2014). The growth and spread of concentrated poverty, 2000 to 2008-2012. Brookings. Retrieved from https://www.brookings.edu/interactives/the-growth-and-spread-of-concentrated-poverty-2000-to-20082012/

Laderchi, C. R., Saith, R., \& Stewart, F. (2003). Does it Matter that we do not Agree on the Definition of Poverty? A Comparison of Four Approaches. Oxford Development Studies, 31(3), 244-274. https://doi.org/10.1080/1360081032000111698

Lok-Dessallien, R. (1998). Review of Poverty Concepts and Indicators. SEPED Series on Poverty Reduction. New York, Social Development and Poverty Elimination Division, UNDP.

Jones, M. (2015). 8 Ways Africa can raise farm productivity and boost growth. The World Economic Forum. Retrieved from https://www.weforum.org/agenda/2015/06/8-ways-africa-can-raise-farm-productivity-andboost-growth/

Michalek, A. (2004). Cores of poverty in Slovakia. Geographica Pannonica, (8), 25-28. https://doi.org/10.5937/GeoPan0408025M

Mitlin, D. (2004). Competition, regulation and the urban poor: A case study of water. In M. Minogue (Ed.), Leading Issues in Competition, Regulation and Development. Edward Elgar Publishing, Cheltenham, UK. https://doi.org/10.4337/9781845420659.00026

Mohamed, M. Z., \& Xavier, J. A. (2015). Poverty alleviation strategies and new economic model in Malaysia. International Academic Research Journal of Economics and Finance, 3(3), 17-31. Retrieved from http://irep.iium.edu.my/43559/1/IARJEF_Mar2015_Mohd_zin_mohamed_\%281\%29.pdf

Moral, M. J. B. (2010). Locating the poor:Spatial poverty mapping of households in Rajshahi City (Unpublished doctoral dissertation). University Sains Malaysia, Penang: Malaysia.

Muhammad bin Idris. (2016). Kemiskinan: Konsep dan Pengukuran. Unit Perancang Ekonomi, Jabatan Perdana Menteri. Kuala Lumpur: Malaysia. Retrieved from http://www.iais.org.my/e/attach/2016/03NOV2016_ zakat_RTD/s1s1.pdf

Muhamed, K., \& Haron, S. (2011). Poverty mapping: An effective approach in determining the poor area-case study of Johor. Retrieved from http://www.statistics.gov.my/portal/download-journals/files/2011/volume1/ contents-poverty-mapping-effective.pdf

Mwabu, G., \& Thorbecke, T. (2016). Rural Development, Growth and Poverty in Africa. Journal of African Economies, 13(1). https://doi.org/10.1093/jae/ejh015

Nair, S. (2010). Moving forward: Its poverty agenda challenges, dilemmas and options for Malaysia in the Proceedings of the Chronic Poverty Research Centre (CPRC), 2010 Conference, 8-10 September 2010.

Nor, R. M., \& Azhar, S. N. F. S. (2016). 1AZAM Aiding Low Income Households in Malaysia. Journal of Human Resource and Sustainability Studies, 4, 293-304. https://doi.org/10.4236/jhrss.2016.44029

Nussbaum, M. (2003). Capabilities as Fundamental Entitlements: Sen and Social Justice. Feminist Economics, 9(2-3), 33-59. https://doi.org/10.1080/1354570022000077926

Robeyns, I. (2005). The Capability Approach: A theoretical survey. Journal of Human Development, 6(1), 93-114. https://doi.org/10.1080/146498805200034266

Roser, M., \& Ortiz-Ospina, E. (2018). Global Extreme Poverty. Our World in Data. Retrieved from https://ourworldindata.org/extreme-poverty

Samat, N., Elhadary, Y. A. E., Hijles, F. M., Ghazali, S., \& Sirat, M. (2012). Poverty and deprivation: Using geographic information system in evaluating the accessibility of households to food retailers in Penang State, Malaysia. e-BANGI, 7(2), 328.

Samat, N., \& Shattar, A. K. A. (2014). Spatial accessibility of colorectal cancer patients to healthcare facilities in Kelantan State: A study on medical geography. World Applied Sciences Journal, 31(10), 1772-1782. 
Samat, N. (2013). Poverty mapping and spatial inequality: Old issue, New Outlook. Paper presented at the International Conference on Sustainability. Universiti Sains Malaysia, Penang, 29-30 Oct 2013.

Samat, N., Elhadary, Y. A, \& Rainis, R. (2016). Tackling Poverty Issues in Malaysia: A Spatial Dimensional Approach, pp 43-50 in Proceedings of 1st International Conference on Society, Space \& Environment, 2 - 3 November 2016, Bali Indonesia.

Samo, J. (2016). 5 Ways Geographic Information Systems (GIS) Can Reduce Poverty. Borgen Magazine. Retrieved from http://www.borgenmagazine.com/geographic-information-systems-to-reduce-poverty/

Schneider, K., \& Gugerty, M. K. (2011). Agricultural Productivity and Poverty Reduction: Linkages and Pathways. The Evans Review, 1(1), 55-74. https://doi.org/10.7152/esr.v1i1.12249

Sen, A. K. (1977). Development as Freedom. Oxford: Oxford University Press.

Sen, A. K. (1987). The standard of living: Lecture ii, lives and capabilities in G. Hawthorn (ed.) The Standard of Living. The Tanner Lectures. Cambridge. https://doi.org/10.1017/CBO9780511570742.003

Sen, A. K. (1992). Inequality Reaxamined. Harvard University Press, Cambridge, MA.

Shamsulbahriah, R. K. A., \& Norma, M. S. A. (2013). Chapter 2 Narrowing Disparities via the New Economic Model (NEM): Is Malaysia Set to Excel beyond Its MDGs Targets MDGs. Millennium Development Goals and Community Initiatives 11 in the Asia Pacific. https://doi.org/10.1007/978-81-322-0760-3_2

Sugden, R. (1993). An axiomatic foundation for regret theory. Journal of Economic Theory, 60, 159-178. https://doi.org/10.1006/jeth.1993.1039

The Sustainable Development Goals Report. (2016). Leaving No one Behind. Retrieved from https://unstats.un.org/sdgs/report/2016/leaving-no-one-behind

United Nations. (2015). Transforming our world: The 2030 Agenda for Sustainable Development. Resolution adopted by the General Assembly on 25 September 2015. Retrieved from http://www.un.org/ga/search/view_doc.asp?symbol=A/RES/70/1\&Lang=E, Oct 1, 2016

United Nations Developing Program (UNDP) Malaysia. (2007). Malaysia: Measuring and Monitoring Poverty and Equality.

United Nations Developing Program (UNDP) Malaysia. (2016). The Millennium Development Goals Report 2015. Retrieved from http://www.undp.org/content/undp/en/home/librarypage/mdg/the-millenniumdevelopment-goals-report-2015.html

Vista, B. M., \& Murayama, Y. (2011). Spatial determinants of poverty using gis-based mapping. In Y. Murayama, \& R. B. Thapa (Eds.), Spatial analysis and modeling in geographical transformation process (pp. 275-296). Springer: Netherlands. https://doi.org/10.1007/978-94-007-0671-2_16

World Bank. (2016). Understanding different dimensions of poverty. Retrieved from http://web.worldbank.org/WBSITE/EXTERNAL/TOPICS/EXTURBANDEVELOPMENT/EXTURBANP OVERTY/0,,contentMDK:20276602 menuPK:7173807 pagePK:148956 piPK:216618 theSitePK:34132 5 isCURL:Y,00.html

\section{Copyrights}

Copyright for this article is retained by the author(s), with first publication rights granted to the journal.

This is an open-access article distributed under the terms and conditions of the Creative Commons Attribution license (http://creativecommons.org/licenses/by/4.0/). 